鴗血液型の遗伝学的研究と育種への応用

藤尾桨久

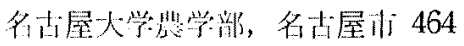

\title{
Genetical Aspects of the Utilization of Chicken Blood Groups in Breeding
}

\author{
Yoshihisa Fujro \\ Laboratory of Animal Genetics, Faculty of Agriculture, \\ Nagoya University, Nagoya-shi 464
}

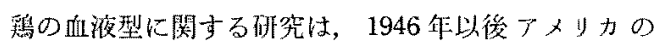
BrILES とイギリスの GILMOUR の2人が巾心となって発 展させた，彼ら快网種兔疫による抗血清老用いて血渡型 を分類した．現在，少なくとも常染色体上に位置する 12

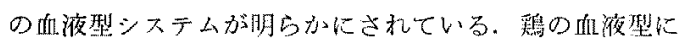
関する総説はすでに多くあり，育種への利用についての

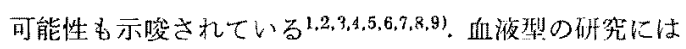
免疫遗伝学てのものに対する興味から進められている免 疫生物学的基礎研究と遗伝的標識として用いる集団遗伝 学的研究および応用的な育種技術的研究とがある.血液 型から育種技術を考えるとき，あまりにも血液型の利用 に期待をかけ過ぎたように思かれるが、現在ではそれに 対する正しい利用のしかたが生まれつつおると思われ b.

血液型の育種人の応用には血液型が個体識别としての 利用と免疫生物学的意味をともなう現象にもとつく利用 が考えられる，前者には品種および系統の特徽の把握， 系統の純粋性の険定, ママーシャルチッタの特徽の把握, 連関している量的形質に関係する遗伝子の選抜などがあ げられる. 後者には実際に組合わせ検定をおこなわずに 組合わせ能力をある程度推定しうること, 組織適合性と の関連性にもとつく経済形質，ウィルス・レセプターと しての血液型による抗病性の育種などがあげられる。 の総説では血液型の遺伝学的研究上育種への応用とのつ ながりを中心として述べることにする。

1. 血液型システム

動物の赤血球がもっている抗原には種特買性と個体特

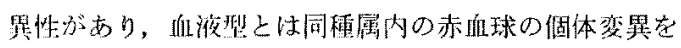
示すもので赫球坊もっている抗原の有無を抗体によっ て分類した型である.この定義は㢸舱の血液型で，ここ で紹介する血液型はすべてこの䁌液型を意昧する。血腹 型の分類のためには，血液型抗原党检Hできる特異性の 高い多くの抗血清が必要であり，抗血掯に上って㭘出さ れる血液型轨㹉の相瓦の誢伝的支配関係定明らかにする ことが重要である、現在，世界各国で用いられている血 液型の分類は BRILES の研究に基礎を置いている。表 1 に示すように，BRILESによって分類された A, B，C，D， $\mathrm{E}$ システムと GILMOUR によって見い出された $\mathrm{L}$ シス テムが一般に使用されている12)，一般には使用されてい ないが，H，I，J，K，Pシステムが BRILESによって追加 されだ、最近，BRILESによって新たにRシステムが追 加された ${ }^{10)}$. システムというのは血夜型抗原支配する 遗伝子が染色体上にしめる位置すなわ方遺伝子座と同じ 意味である。血液型システムの記号についてはすでに世 界各国でほほ統一した記号が脚られているが，個々の

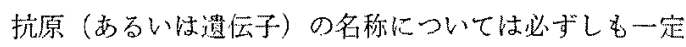
してい/小. OKaDA $5^{11,12,13,14}$ は F, G, H 3 つのシス テム分析したが，のbに ステム，FとHシステム纳同一システムでBRILFs $の$ A システムに属することが明らかにされた. GILmouR ${ }^{15)}$ に よって独古のシステムとして報皆された

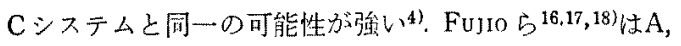
$\mathrm{B}, \mathrm{D}$ システムと他の䔬った 4 つのシステム (未同定)を 分析したが，このう方のFシステムは BRILESの C シス
1975. 4 . 
脽尾

表1. 鵎の衈液型シ又テム

\begin{tabular}{|c|c|c|c|c|c|c|}
\hline シ 㕛厅テ記号) & $\begin{array}{l}\text { 刘 立竞 } \\
\text { 遗伝 }\end{array}$ & 抗原の存在 & 関 & 発 表 者 & 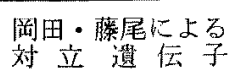 & 䓔 \\
\hline A & 参数 & $\mathrm{RBC}$ & \multirow[t]{2}{*}{$\mathrm{E}, \mathrm{J}$} & Briles, Gilmour & $F, H, P$ & \multirow[b]{2}{*}{ 組織邀合性 } \\
\hline$B(G)$ & 多数 & $\mathrm{RBC}, \mathrm{WBC}, \mathrm{TCC}$ & & \multirow{2}{*}{$\begin{array}{l}\text { Briles, Gilmour } \\
\text { Briles, Gilmour }\end{array}$} & $\begin{array}{l}\text { A, B, C, E, G,I, K, } \\
\text { L, M, BM, MO }\end{array}$ & \\
\hline $\mathrm{C}(\mathrm{N})(\mathrm{F})$ & 多数 & RBC, WBC & $\mathrm{P}$, 冠毛, 碊性白 & & $\overline{\mathrm{C}}, \mathrm{W}$ & 縕織適合性 \\
\hline $\mathrm{D}$ & 多数 & $\mathrm{RBC}$ & $\mathrm{H}$ & Briles & $\mathrm{Q}, \mathrm{S}$ & \\
\hline $\mathrm{E}$ & 多数 & $\mathrm{RBC}$ & $\mathrm{A}$ & Briles & $\mathrm{U}, \mathrm{R}$ & \\
\hline $\mathrm{H}$ & $\mathrm{H} 1, \mathrm{H} 2$ & $\mathrm{RBC}$ & $\mathrm{D}$ & BRILES & & \\
\hline I & $\mathrm{I} 1, \mathrm{I}_{2}$ & $\mathrm{RBC}$ & & BRILES & & \\
\hline $\mathrm{J}$ & $\mathrm{J} 1$ & $\mathrm{RBC}$ & A & BRILES & & \\
\hline K & $\mathrm{K} \perp$ & $\mathrm{RBC}$ & & BRILES & & \\
\hline $\mathbf{L}$ & $\mathrm{L}_{1}, \mathrm{~L}_{2}$ & $\mathrm{RBC}$ & & Gilmour & & \\
\hline $\mathrm{P}$ & Pl & $\mathrm{RBC}$ & C & BRiles & & ラウス肉腫 $\mathrm{B}$ \\
\hline $\mathrm{R}$ & $\mathrm{R} 1$ & $\mathrm{RBC}$ & & BRILis & & $\begin{array}{l}\text { 它ルス・V } \\
\text { セプター }\end{array}$ \\
\hline
\end{tabular}

$\mathrm{RBC}$ : 赤血球 $\mathrm{WBC}$ : 白血球 $\mathrm{TCC}$ : 組織培養細胞

テムに属することが朋らかになっだ。

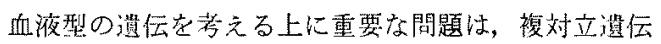
子が多いということである。血液型抗原の頲伝につい

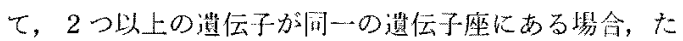

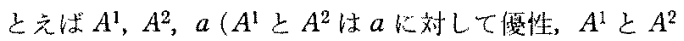

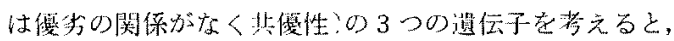
$A^{1} / A^{1}, A^{1} / A^{2}, A^{1} / a, A^{2} / A^{2}, A^{2} / a, a / a \bigcirc 6$ 禹の溃伝子 型が生じ，表現型は $A^{1}, A^{1} A^{2}, A^{2}, a$ となる。このよう

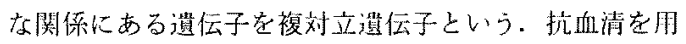
いて䁒液型を分類することは精黀の高い抗原抗体反応を

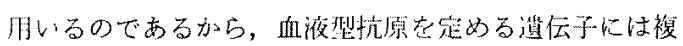
刘立䙹伝子获多いの垱然のものと思われる $A, B, C$, $\mathrm{D}, \mathrm{E}$ システムは複対立造伝子からなっている. $\mathrm{B}$ シス テムでは抗原閒の交文反底がみられ，少なくとも210血 液型国子に分けられるが，ての各々が単一の造伍子に刘 芯するのでかく，遗伝子としては $[5,6,7,8,9,12,13$, $14,21]$ 上か $[1,2,3,4,9,13,14,21]$ 上加 $[4,6,11$,

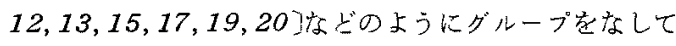
いる.これらのダループは $B^{1}, B^{2}, B^{13}$ 遗伝子で,このよ うな血液型因子のグルーブを phenogroupという19!. 牛 のBシステムの血液型，七トのRh 式血液型で phenogroupがみつけられ，各々の血液型因子に対する抗血清 が得られている、䟼では血液型因子に対する抗血清作成 には成功していない。血液型肉子が隣葌して連関してい

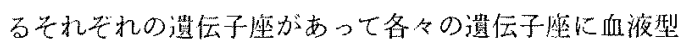
月子の単一の选层子があると考えられる。この隣接した

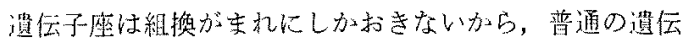
子分析では1つの遭伝子座のようにみえるが，実際には

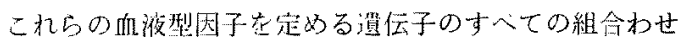

があることになる。すなわら，隣接した遗伝子座数（血 液型因子数）を $n$ とすれば，複対立遗伝子として認識さ れる鼾伝子数は $2^{n} て ゙$, 血液型因子の数が增すごとに急 激に複対立邀伝子数が増加することになる.したがっ て，血液型造伝子が血㖡型因子のグループであることか ら複刘立筧伝子数が多数であることが説明される，Hと Iシステムは 2 抗原 2 遗伝子よりなり牛の FVシステム のように○型がなく，表現型之选伝子型上一致する。

J,K, R システムは1抗原で, L, Pシステムでは 2 抗原 が見い出されている。

血液型澬伝子座の間に連関があるかどうか一同一染 色体上にあるかどうかを明らかにしておくことは，血液 型を標識遗伝子として用いるためには電要である.12の 血液型シスデム(㙋伝子座) のうも，A-E-J 頲伝子座， D-H 选伝子座， C-P造伝子座では連関がみられてい

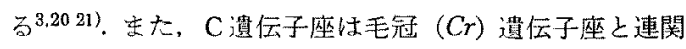
がみられ $2^{22}, \mathrm{Cr}$ 遗伝子座より悽性白 $(I)$ 遗伝子座に近W 連関老した18). 故に，これらの血液型遺伝子によって 鷄染色体の8 本が摽識されるといえる。最近では, 12 の 血液型システムのほか心植物性血球凝集素 (PHA) p組 織血球凝集素 (THA) によって检出される赤血球型28), アロタイプの㛟出 ${ }^{24)}$, 電気泳動汒による血清蛋白質抢よ

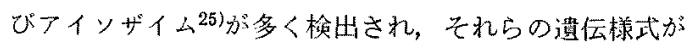
明らかにされるに至り，睬染色体数 $n=$ 約 3902 分の1 以上がこれらの遺伝子によって標識されるといえる.

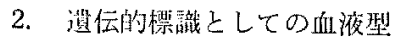

1) 品悸むよび系統の特徽

血液型構成から，ある血液型遗伝子がある品種に特異 的に見い出されるものと，普逼的にどの品種にも見い出 


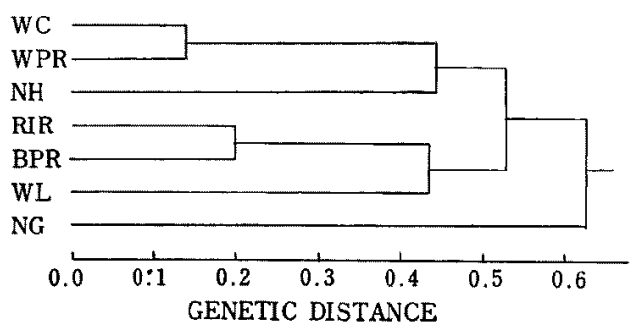

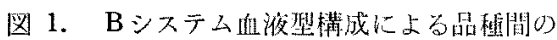
选后的颣似閶係

されるものとがあることが知られている，たとえば， $B^{A}$

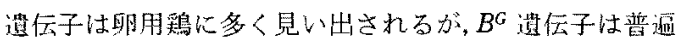
的分材走している14.26). 杂た，一般に白色レダホーン （WL）は $B^{A}$ 遗伝子をもち $B^{B}$ 遗伝子をもたない，欌斑プ リマスロック (BPR) は $B^{A}, B^{G}, B^{K}$ 遗伝子を, マード・ フイランド・レッド (RIR) とニニーハンブシャ(NH) は $B^{G}, B^{K}$ 遺伝子を，名古屋 $(\mathrm{NG})$ は $B^{B}, B^{G}$ 頲伝子を， 白色プリマスロック(WPR) 上白色コーニッシュ (WC)

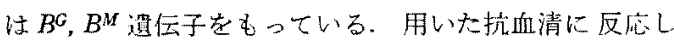
六い○タイプがNH, WPR, WCでみられる26.2). この ようにBシステムだけでも品璉の特徽を明らかにするこ とができる，血液型满成苍もとにして，品種間の煩似度

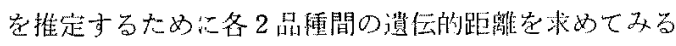

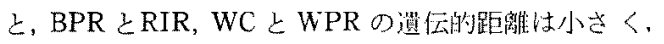
WL と NG, WC とNG の灌任的距離は大き加った（成 1) ${ }^{27)}$. こ机は BPR こ RIR, WC こWPR とに高い頪似 度がみられること惹䀳している。

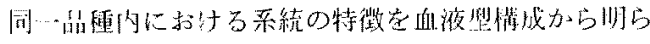

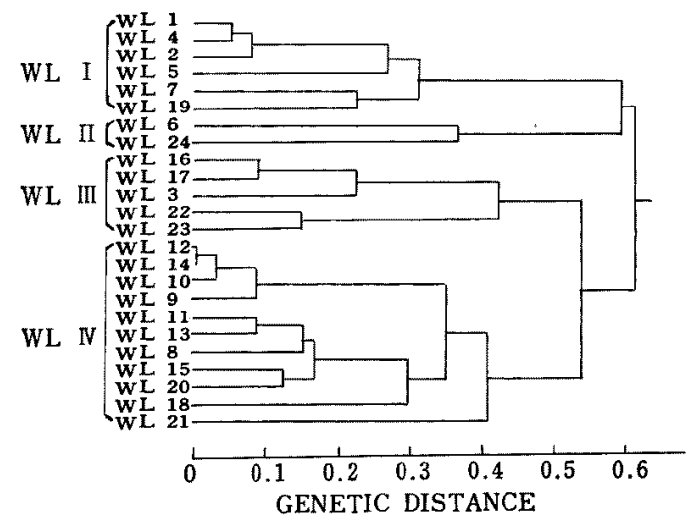

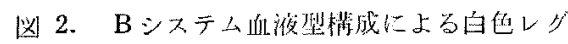

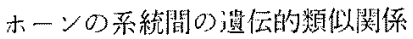

(50\%の類似度すなbち遺任的距崔 0.5 で 4 グ ループに分けられる)
かにすることができる、たとえば，WLの番統はBシス

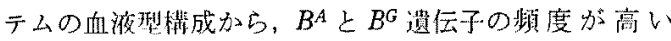
$\mathrm{AG}$ タイプ， $B^{A}$ と $B^{M}$ 遙伝子の頻度が高い $\mathrm{AM}$ タイプ,

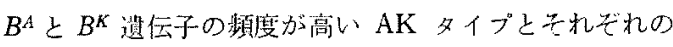
タイプが混合したむのの4つのグループに分けられ る26)。このようにBシステムの血液型だけでも采統の特

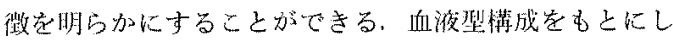

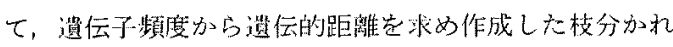

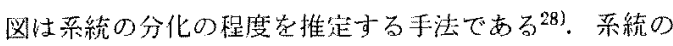
分化が著しい品㮔と艺うでない品種がある。たとえば， 血液型詷查によって得られた各々の柔統のBシステム血 液型遗任子頻度をむと它して作成された枝分かれ四か b, WL では大きく 4 グループ, WPR では 3 グループに 分けられたが，BPR，RJR，NH，NG，WCでは系統の分 化は著しくなか力太、図 2 は WL 24 系統について

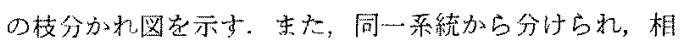
反反復選抜法がおこなるれた 2 系統間の遭伝的距離は大 きく、コマーシャルチック生産に用いられている父系と

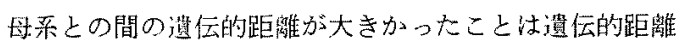
を求めることにより実際に組合わせ検定を打こなるずに 組合わせ能力范方型度推定しうることを示唆してい b.

2) 䒺統の純粋性の検定

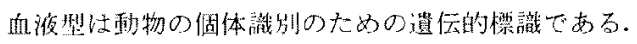

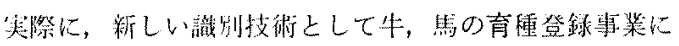

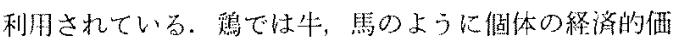
值が大芜畜ほど夫きく去いために血統登録として利用さ れにくい。しかし，㟧種および采統の特幑が集団の血液 型楧成から把握できるのであるから，大家畜に扮ける個 体識别を集団識别としての利用が考えられる。采統内集 団の血液型棈成它朋らかにすることは系統の純料性（集 団の䢙伝的整一性）艺知る上に重要である，特に，種鴭 あるいは原種䳕の整一性はコマーシャルチックの整一性 家得るために要求される. 血液型邀伝子が量的形質に関 係する选伝子乞連閣しているとすれば，血液型邀伝子の 整一性は量的形質の整一性荙推定する手段となる。

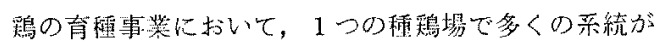
保持され、しばしば同時期に多くの系統の維持選拔のた めに梛化育成加出されている。この上うな状洗のもとで は系統の異なる個体が福入与る危险性が高いたをえ ば，俱った個体の混入事が $8.89 \%$ あったことが血液型

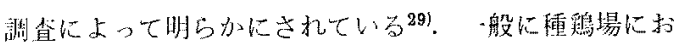
いて 12 15\% 程度誤った個体が混入なる危倹性が推定 される：これが種鵎亦るいは原種鵴で起こったとすると コマーシャルチックの著しい不整一性をるたらすことに 
なる、したがって乐統維持のために系統集国内の血液梨 模成を指標としての血液型の利朋が電要である。多価兔 疫抗血清（未吸湆の免疫血清を多種類混合したるの）它

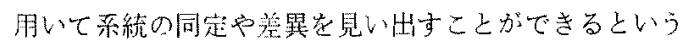

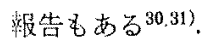

3) コマーシャルチックの特徽の把握

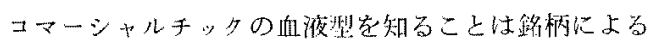

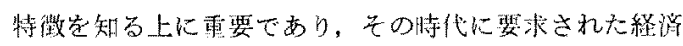

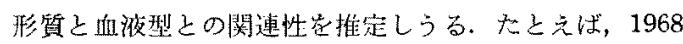
〜1973年に市賏されたコマーシャルチッタ（レイヤー） の血液型調查から，Bシステムの血液型楧成はどの銘柄 においても1つあ尚いは2つの人テロ型で占められ，鉻 柄によって權成される遗伝子名異なっていた。 また，同 一銘柄においてマレック病多発にともない構成される遗 伝子に変化がみられた

3. 血液型々経济抢質上の関連性

血液型が経剤形質と関㮇があるのではないからら考 え方はかなり古くからあった，最初は血液型と体質が考 えられたが，元の後具体的な形質について比較研究され るようになった。鷅においても血液型と経佩形質（受精

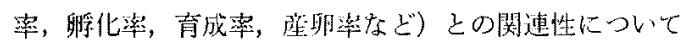
の䡋告が多く庄されている。

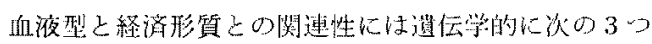
の埸合が考元られる。

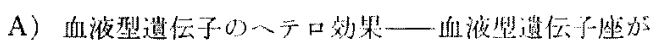

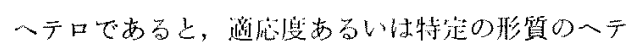
ローシス加現われる嚗合

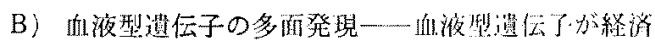
形質に直接安たは間腰に闒与している場合

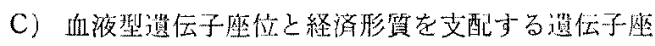
との逨閶

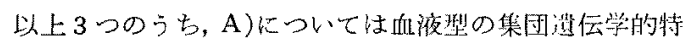

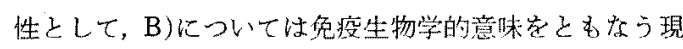
象として説明することができるのであとで述べることに する.C)について考劣る場合，経済形質は産卵数，即重， 体重などとして把握され，常に「程度の差」として取り

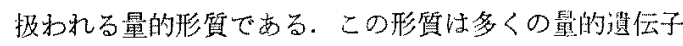
によって支配され，选伝子間の相互作用および環境によ

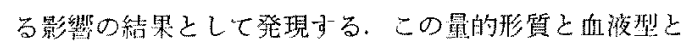

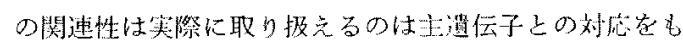

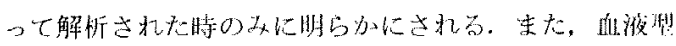

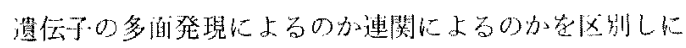

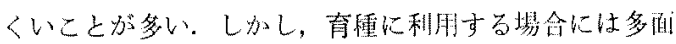
発現と連関とは区则して用いることが重要である。

ALLEN とGILMOUR ${ }^{33)}$ は 2 つの刘立造伝子 $B^{13}$ と $B^{14}$ と
が比洨できるような遗伝子憋の組合かせで交配して，切 化等, 成長期之成整後の生存慗, 産卵染について調べた.

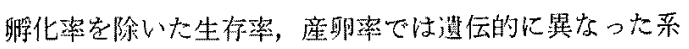

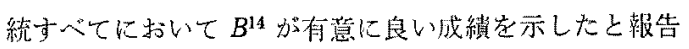
している. OKADA $5^{34)}$ 恃 Bシステムの対立遗伝子の効果

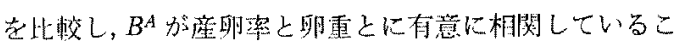
とを示した. JoHNSON ら ${ }^{35}$ は産畉率について選拔された

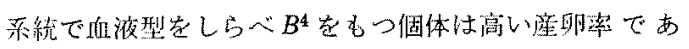

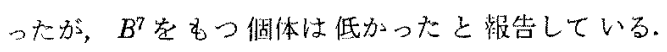

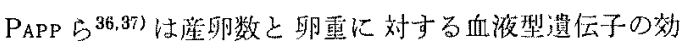
果をしら人、，件電については有意な効果が巫られなかっ

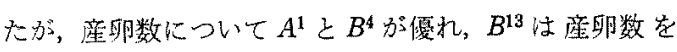
低める傾向があると報告し，さらに研究它続好， $A^{2}, A^{6}$, $B^{5}$ 滈い麾卵性と関連しており， $A^{2}$ と $B^{4}$ をる個体は 重い卵重示したと報告している. BRILES ${ }^{38)}$ は $D^{1} / D^{1}$ の 卵重が $D^{2} / D^{2}$ より $2.3 \mathrm{~g}$ 重く, $D^{3} / D^{3}$ より $1.1 \mathrm{~g}$ 重い上

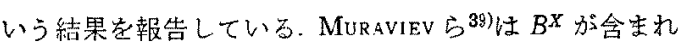
る溃伝子型のものは高い産卵萃省し，この結果が系統 によって強かったり弱かったりすると報告している. 一

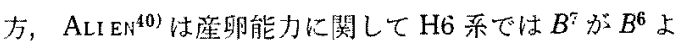
り良い成績を寺したが H13 系では括に $B^{6}$ が良い成績を 示したと战皆している.MCDERMID ${ }^{41.42)}$ は Bシステムの

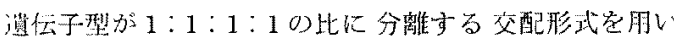

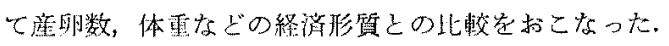

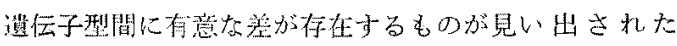

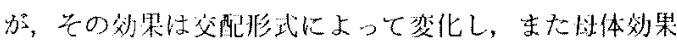
による畉分もかなりあると推測している。さらに䃘究在 続けて，見い出される有意な敨は必ずしも一定の傾问が みられないと絬諭している，以上の結果を総括してみる と，Bシステムが座卵性に關連している可能性があり， 系統によって央の效果方变化沶る事実加ら，B血液型遗 伝子座に近接した应卵性に関与す可主造伝子の存在が考 えられる.これに關連して，BRILES ${ }^{38)}$ はD息伝子座に近 接した即の大きさ支配子る主溃伝子の存在を示晙して いる. 最近, NORDSKOG $5^{43}$ は $B^{1} / B^{1}$ 血液型が成鵎の高い 死亡慗をもたらすとと索欢つけ，Bシステムの遗伝子型 が4つの木型と6つのへテロ型が分嚁するWLの集

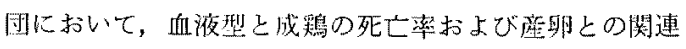

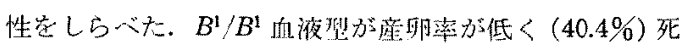

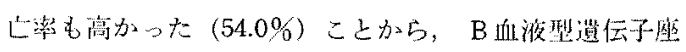

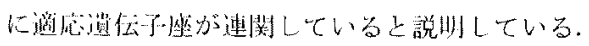

4. 面液掹の集四遗伝学的特性

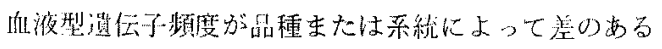
ことは明らかで，これ荤用いて集団の棈造分析などがお こなわれ，鵎においても血液型の多型現象が知られてい 


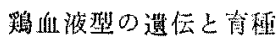

る.鴊の近交系をしらべると，かなり高度に近交された 系統においても宓ずといってすよいほど血液型遭伝子の 分離が肎い出される ${ }^{15,44)}$. Fuj10 と Kondo は WI.の閉鎖 集団として維持されている 24 系統のBシステム血液型 をしらべ，各系統は2つあるいは3つの対立埧伝子の組 合わせで棈成され維持されていることを明らかにした。 なおこれらの集団内ではへテロ個体が理論値上り多いこ

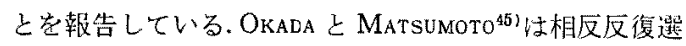
抜法によって育種されている2柔統について3世代にb たってBシステム血液型の筫伝子型の推移を追究し， 一 テロ個体の頻度がその期待值よりる明らかに高く，それ をさらに産卵性について選抜をおこなうとへテロの頻度 が一層高まること報告している。このようなことから， Bシステムの血液型はへテロの適応度が高いことによっ て維持されている平衡多型であると考えられている.

Bシステムにおいてへテロ効果が瞹化率, 生存染, 産 卵率において見い出されている. BRILES ${ }^{46)}$ は後代のBシ ステム血液型のへテロ個体が $0,50,75$ ，および $100 \%$ に

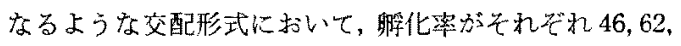
71 および78\%となり，へテロの割合が多い組合わせほ

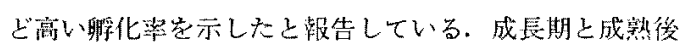
の生存㳯について. BRILES と ALLEN ${ }^{47)}$ はBシステム血液 型がへテロのものがホモのものに比ベて優れていること

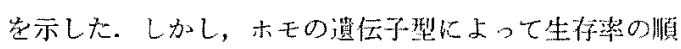

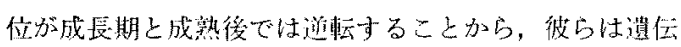
子の優位性の睦期に上る交替がへテローシスの一因であ るか子知れないと示惨している. ALLEN こ GILMOUR ${ }^{33)}$

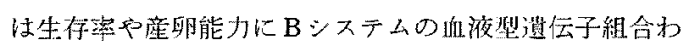

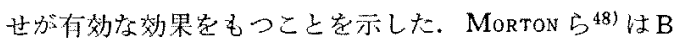

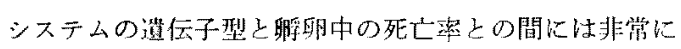
高い関係夯あり，その人テロ効果は超優性によるものと

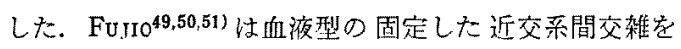
用いてBシステムの血液型と他のシステムの血液型およ び形態的形質 (羽装, 冠形など) のへテロ効果をしらベ, ヘテロの遗后子型が有利と考えられる遗伝子座の1つが Bシステムの血液型であること省明らかにした。 へテロ

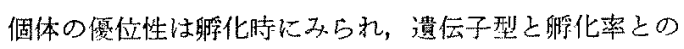

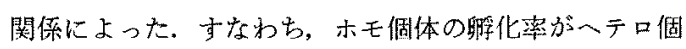

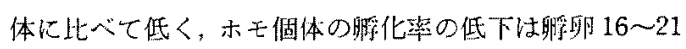
日日に括ける死しに起国した。

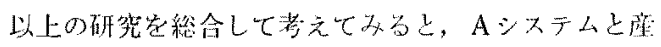

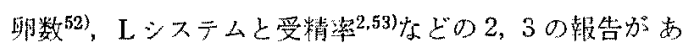
るが，鷅のBシステムは適応度と何らかの形で関連して いることは明らかで，一テ口個体は亦毛個体より高い適 応度をもっている. 特に, 卯化繁および生存率に関速性
帉みられる，組命わ能力を考える上に，系統間のBシ ステムの血液型構成が抢互に異なるように組合わせをす ることが䣙化慗および生存慗に有效と考元られる。

5. 血淮型と組㵶適合性

1) 血液型之移植

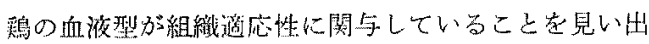
したのはSCHIERMAN と NORDSKOG ${ }^{54}$ である。彼らは血淮 型谓伝子のわ加った系統老用いて，睑化後16日命の蜼で

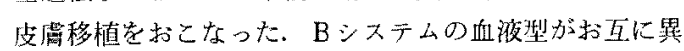

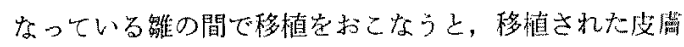
は手術後 12 日目に拒絶反店菊示し眖落した(Bシステム について不適合のもの).しかし，Bシステムの血液型が 打互に同じである觹の間では A，H，Lシステムが異な っていても，手術得40日目においても生着していた（B システムについて啇合のもの．Bシステムが移植に関与 していることはその後多くの研究者によって確認され $\star^{55.56 .57)}$. Cシステムについては CRITTENDEN ら ${ }^{58)}$ は否定 的な結果を報告したが, SCHIERMAN と NORDSKOG ${ }^{59)}$ はB システムほど強くないが組織適合性座であること胃い 出している。 Bむよの゙Cシステムの抗原は他のシスデム 之異って赤血球のみならず白任球と組織細胞にも存在す

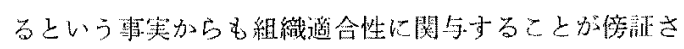
学每 60.61 .

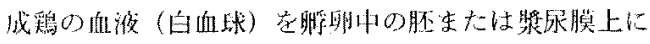

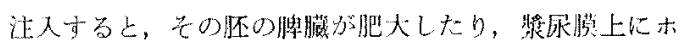

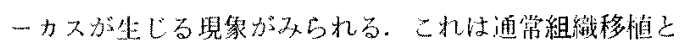
逆の関棌になっている免没反心で，移植組織刘桼主反心 (GVH反灾) という. Bシステムが組織進合性坐である

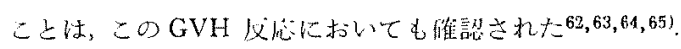
CシステムについてはGVH 反応に関与している可能性

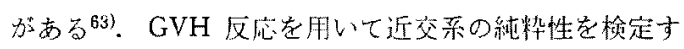
ることが容易であるという報告がある66).

2）血液型上受精

受精現象には免疫（組織適合性に類似した現策として） か゚関与していることが考えられる。たとえば， ウ二の卵 己精子の表面に注特異长反应物質が存在し，これらの物 質が抗原抗体反応の形で互に作用し，卵子精子の融合が 生じ精子办卵膜内にとりこ定れるここ肪知られている。

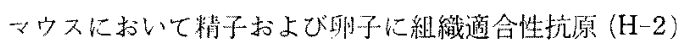

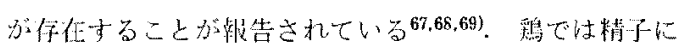

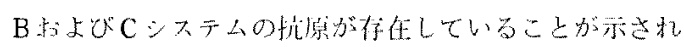
てい弓⿱日十).

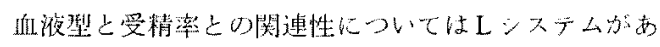
げられ，これはーテロ効果によると結論されている2,53). 最近，Bシステムの血液型と受精率との関連性について 
の研究が，MORTONとGILMOUR ${ }^{71}$ によって店された。彼 らは雄の遗伝子型上同じ选伝子型㫐るつ比に交配した場

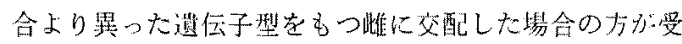

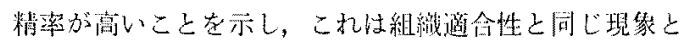

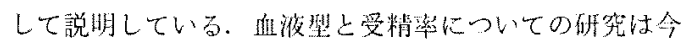
娞組織迺合性に柱目してなされるへきであるう。

3) 血液型之抬体原生

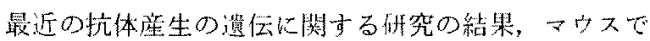
免疫応答を支配する Ir (Immune response) 誢伝子存 在が知られるようになりこの选伝子はH-2 遗伝子座の 中存在するここがわかり，Ir-1頲伝子といわれてい

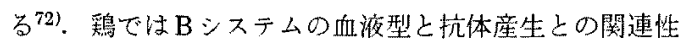
が報告されている。 PEVZNER ら ${ }^{73)}$ は $B^{1} / B^{1}, B^{1} / B^{2}$, およ び $B^{1} / B^{19}$ の成舀にサルもネラ菌と牛血清ノルブンの 混合物を投与して，これらの抗体産生をしらく，抗サル モネラ抗体に扮いて $B^{1} / B^{2}$ 壮 $B^{1} / B^{1}$ 上り离い抗体価家示 したと報告している．彼らは $B^{1}$ へテロ個体が $B^{1}$ 木モ個 体より抗体産生がよいことは成鷄の生存性が高いことに

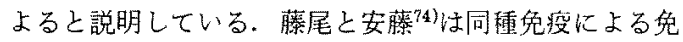

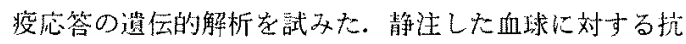
体産生の程度に系統差加功られ，その系統差怯 donorrecipient 間の晌液型遗伝子の異る程度によって生ずる のではなく recipient $の$ 遗任的要国によった（図了）ささ らに，こ机らの2 系統のF，分離個体閪で免疫して抗体

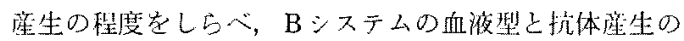
程度が逨関していた。これはマウスのIr-1道伝子上同じ Ir 遗伝子の存在走している。また，翼種兔疫に扮いて

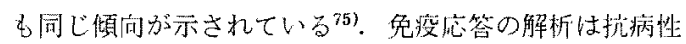

育樗の1つの手がかりとなるうし，この力面の昨究は将 来借期待される。

6. 血液型と抗病性

血液型と抗病性との関連性がみら机た旰究怕自病と マレック病で韩告されている76,77,78.79). HASEN $5^{76)}$ は. B システムの血液型が $B^{19} / B^{19}, B^{19} / B^{21}, B^{21} / B^{21}$ に分蜼す

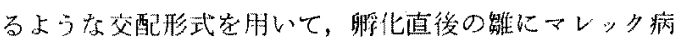

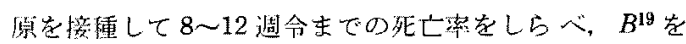
もつ個体は $29.0 \% ， B^{21}$ 它個体で士16.0\%の結果を 得地，さらに，野外での自然感染による調査に打いて マレック病に上る死亡率が $B^{21}$ 它的個体上り $B^{19}$ をむ つ個体の方が高い結果老得て，彼らは $B^{21}$ をるつ個体よ り $B^{19}$ をつ個体がマレッタ病にかかりやすいと結論し た. NISHIMURA $5^{78)}$ は自然感染において内落型白血病と マレッ病による死亡率が $B^{A}$ をるつ個体がもたない個 体より低いこと報告している。最近，JoHnson ${ }^{(9)}$ は $B^{2}$ と $B^{5}$ が $50 \%$ つつ分離す台WL R ラインに福いて 1963 年の調查で $B^{5} / B^{5} か ゙ B^{2} / B^{2}$ と $B^{2} / B^{5}$ りライフスパンが 短いことをみつけ， $B^{5} / B^{5}$ 永コレック病付対して感受性 が高いことによるとした。东た，1965 年の調査で同じ傾

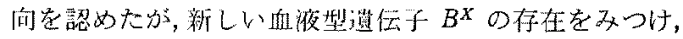
$B^{5} / B^{x}$ が $B^{2} / B^{5}$ と同じライフスバンであったので, $B^{X}$ は $B^{5}$ より突然变異によって生じたとした。彼は $B^{X}$ 抗原が $B_{5}$ 抗原物質の一湆分が觉化してマレック病に対する抵 抗性を獲得したと考えた。

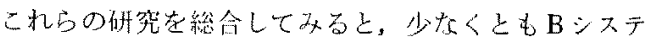
ムの直液型が何らかの形で白血摧，マレック病に対する 坻抗性と関速していると考えられる。この閣連性は免疫

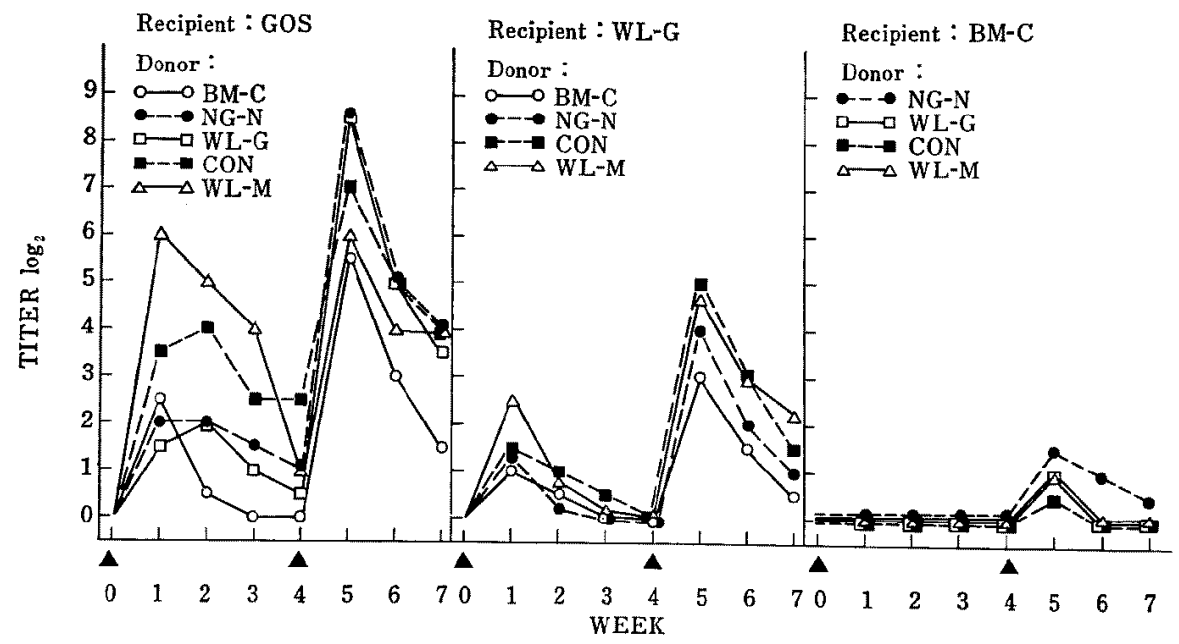

図 3n同棘免疫による抗体産生の系統差（ム抗原注入） 


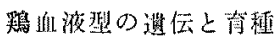

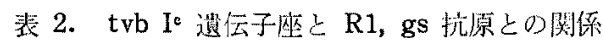

\begin{tabular}{|c|c|c|c|c|c|}
\hline \multicolumn{2}{|c|}{ 選伀子座 } & \multicolumn{2}{|c|}{ 感要性 } & \multicolumn{2}{|c|}{ 抗原 } \\
\hline tvb & Inhibitor & $\mathrm{B}$ ウイス & Eウイルス & $\mathrm{RL}$ & gs \\
\hline$b^{s 1} /-$ & $I^{\theta} /-$ & $\mathrm{s}$ & S & + & + \\
\hline$b^{s 1} /-$ & $I^{e} /-$ & $\mathrm{S}$ & $\mathrm{R}$ & - & + \\
\hline$b^{r} / b^{r}$ & $I^{b} /-$ & $\mathrm{R}$ & $\mathrm{R}$ & - & + \\
\hline$b^{s 1} /-$ & $i^{x} / i^{q}$ & $\mathrm{~S}$ & $\mathrm{~S}$ & + & + \\
\hline$b^{s 2} /-$ & $i^{n} / i^{\text {r }}$ & $\mathrm{S}$ & $\mathrm{S}$ & - & - \\
\hline$b^{r} / b^{r}$ & $i^{*} / i^{*}$ & $\mathrm{R}$ & $\mathrm{R}$ & - & - \\
\hline
\end{tabular}

応答の違いに上るのかまたは血液型抗原がウィルスが細 胞に吸着侵入することができるか否が決定するとのウ イルスに特暴的なしセプターであるという2つの仮説が 誟えられる。

最近，ラウス肉腫ウィルスの感受性に関する研究で $\mathrm{R}$ システムの血液型抗原がレセプターであることが明らか にされだ0).ラウス肉腫ウィルスのサブダループA，B， C㧍よびEウィルスに対する宿主細胞の感受性と抵抗性

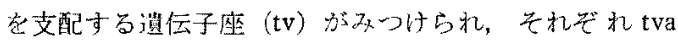

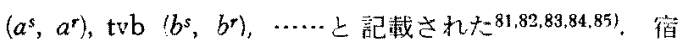

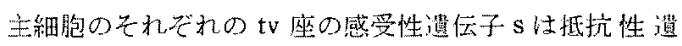
后子 $\mathrm{r}$ に対して完全あるいは不完全榃性であり，培養さ れた細胞あるいは生体内細胞のウィルス・レセブタ一走

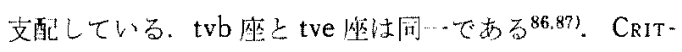

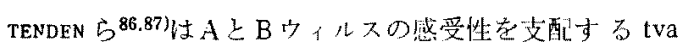
と tvb 夾の遗伝子が分蜼しているRPRL ライン100k ふいてRシステムの血液型とBウィルスの感受性との関 速安明らかにした。すなわち，Rl抗原皆むつものはBウ イルスに刘して感受性があり，居たないむのは抵抗性で あったしかし，Dekalbライン 2 に执いてはRl抗原を あつ個体は感受性であるが，あたない個体に感受性のも のと抵抗性のものと就分離していた。彼らはBウィルス に対する感受性遺伝子 $\mathrm{tvb}^{5}$ が 2 つに分けられるとし Rl 抗原の存在に上る感受性湜伝子 $t v b^{5 \mathrm{I}}$ ¿ $\mathrm{Rl}$ 抗原等もた ない感受性谌伝子 $t v b^{s 2}$ とした。

Eウィルスの感受性は tve（tvb）潜伝了座己感受性老

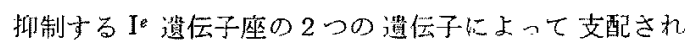

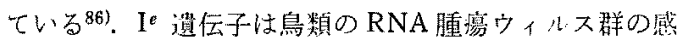
染と関連した抗原複合体である gs (Group-specific) 抗原

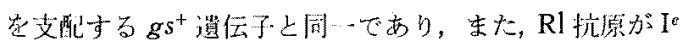
望伝子の存在なしにgs抗原の山現に閔与していること

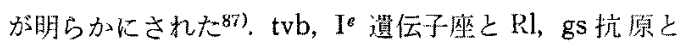
の関係を表 3 に要約する.

ラウス肉腫ウィルスの例のように，血液型と抗病性と
の関連性に㧍いて血液型抗原がウィルス・レセブターで

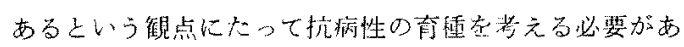
3 .

造侁学が育種の基礎学であるということは，子でに常 識となっていることであるが，溃伝学と育匭とのつなが りには大きな空閐がみられる。鵎の侐液㤠についても例

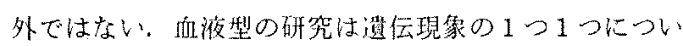

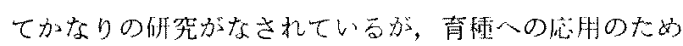
にはこれらの1つ1つの埧厓現缘いかにして総合しう

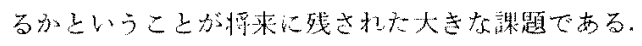

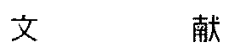

1) Briles, W. E., World's Poultry Sci J 16: 223-242. 1960.

2) Gilmour, D. G., Brit Poultry Sci 1: 75-100, 1960.

3) Briles, W. E, Ann NY Acad Sci 97: 173-183. 1962.

4) Grlmour, D. G., Ann NY Acad Sci 97: 166-172. 1962.

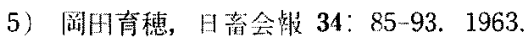

6) McDrrmid, E. M., Vox Sang 9: 249-267. 1964.

7) Nornskoc, A. W., World's Poultry Sci J 20: $183-$ 192. 1964 .

8) Gilmotr, D. G.. Agricultural Science Review 7 : 12.22 .1969$.

9）光本孝次, 家侪会誌 6：59-67. 1969.

10) Briles. W. E., and L.B. Crittenden, Poultry Sci 50: 1553.1971.

11) Matsumoto. K., and I. Okada, Japan J Genet 36 : 257-267. 1961.

12) Okada, I., S. Takagi, and K. Matsumoto, Japan J Genet 37' 102-109. 1962.

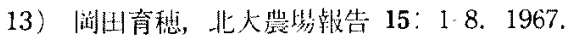

14) Okada, I., and E.M. McDermic, Jap J Zootech Sci 41: 319-325. 1970.

16) Gilmour, D. G., Genetics 44: 14-33. 1959.

16) Funlo, Y., K. KanoH, and K. Kondo, Japan J Genet 45: 23-33. 1970.

17) Fujo, Y.. and Z.A. Ezzeldin, Jap J Zootech Sci 
45: 412-418. 1974 .

18) Fujro, Y., ABRI 3: 26-28. 1974.

19) HǍla, K., and F. Knížttova, XIIth Europ Conf Anim Blood Grps Biochem Polymorph 385-387. Warsaw. 1968.

20) Briles, W. E, Poultry Sci 37: 1189. 1958.

21) Briles, C. O., and C.P. Seft, Proc XII Inter Congr Genet 1: 278. Tokyo. 1968.

22) Briles, C.O., W.E. Briles, and J.H. Quisenberry, Poultry Sci 29: 750. 1950.

23) 藤尾法久, SABCO J 1: 21-27. 1965.

24) SaKalba, D., Arch Immun Ther Exp 16: 1-11. 1968.

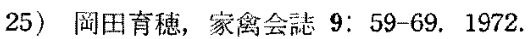

26) Fujlo, Y., and K. Kondo, Jap J Zootech Sci 41: 593-600. 1970.

27) Natsume, N., Y. Fujo, and K. Kondo, Jap J Zootech Sci 43: 712-718. 1972.

28) Fujio, Y, Jap J Zootech Sci 44: 174-180. 1973.

29) PaPP, M., XIth Europ Conf Anim Blood Grps Biochem Polymorph 455-458. Budapest. 1970.

30) Mitsumoto, T., and Y. Yamada, Poultry Sci $\mathbf{4 0}$ : 1701-1704. 1961.

31) Briles, W. F, World's Poultry Sci J 27: 120-131. 1971.

32) Fujlo, Y., ABRI 2: 18-19. 1973.

33) Allen, C. P., and D.G. Gilmour, Genetice 47: $1711 \cdots 1718,1962$.

34) Okada, I., T. Hasegawa, S. Sekidera, H. Shimizu, and $\mathrm{Y}$. Hachinohe, Jap J Zootech Sci 37: 302 311. 1966.

35) Johnson, L. W., C. H. Moore. and G. J. Cotther, Poultry Sci 48: 1827. 1969.

36) PAPP, M., Magy Ao Lapja 23: 580-583. 1968.

37) Papf, M., L. Szajkó, and J. Schmidt, XIIth Europ Cont Blood Grps Biochem Polymorph 491 498. Budapest. 1972.

38) Brilfs, W.E., Poultry Sci 51: 1788. 1972.

39) Muraviev, V. I., S. Samodelkina, and I. Sovetova, XIIth Europ Conf Blood Grps Biochem Polymorp. 499-500. Budapest. 1972.

40) Allen, C. P., Ann NY Acad Sci 97; 184-193. 1962.

41) McDermin, E. M., Blood Groups of Animals 173178. 1965.

42) McDermid, E. M., Poiymorphisms Biochimiques des Animaux 223-230. 1966.

43) Nordskog, A. W., W. A. Rishell, and D. M. Biggs, Genetics 75: 181-189. 1973.

44) Briles, W. E., C.P. Allen, and T. W. Millif, Genetics 42: 631-648. 1957.

45) Okada, I., and K. Matsumoto, Japan J Genet 37 : 267-275. 1962.

46) Briles, W. E., Genetics 39: 961 962, 1954.

47) Briles, W.E., and C. P. Allen, Genetics 46 1273-1293, 1961.
48) Morton, J. R., D. G. Gilmour, E. M. McDermid, and A. L. OGden, Genetics 51: 97-107. 1965.

49) Fuj10, Y., Japan J Genet 46: 181-189, 1971.

50）藤尾芳久，「实䮖動物の開発・改良』シンポジウム維 演集 44-53. 1972.

51）藤尾苊久，日音会韩 44 (別号)：49. 1973.

52) Shult $\%$, F. T., and W. E. Briles, Genetics 38: 34-54. 1953.

53) DeSilva, P. L. G., Genetics 51: 41-48. 1965.

54) Schierman, I. W., and A. W. Nordskog, Science 134: 1009-1009. 1961.

55) Craig, J. V., E. M. McDermid, Transplantation 1: 191-200. 1963.

56) Gilmour, D. G., Heredity 18: 123-124. 1963.

57) Gleason, R. E., and R. C. Fanguy, Transplantation 2: 509-514. 1964.

58) Crittenden, L.B., L.W. Johnson, and W. Okazaki, Transplantation 2: 362-374. 1964.

59) Schierman, L. W., and A. W. Nordskog, Transplantation 3: 44-48. 1965.

60) Schierman, L. W., and A. W. Nordskog, Science 137: 620-621. 1962.

61) Benda, V., K. Hála, and I. HlozáneK, XIIth Europ Conf Blood Grps Biochem Polymorph 437-440. Budapest. 1972.

62) JAFEE. W. P., and E. M. MCDERMid, Science 137: 984. 1962.

63) Fujio, Y., Japan j Genet 45: 225-232, 1970.

64) Fujro, Y., Symposium on Immunobiology 4 43-45. 1970.

65) Schierman, L. W., World's Poultry Sci J 21: 6-11 1965.

66) Sharon, R., Poultry Sci 44: 1612-1614. 1965.

67) Vojtiskova, M., Nature 222: 1293-1294. 1969.

68) Golvberg, E. H., T. Aoki, F. A. Borse, and D. Bennet, Nature 22S: 570-572. 1970.

69) Srmmons, R. L., and P.S. Russel, Ann NY Acad Sci 129: 35-45, 1966.

70）光本孝次，家禽学会春季大会要旨 23-24. 1965.

71) Morton, J.R., and D.G. Gilmovr, Theoretical and Applied Genetics 42: 111-118. 1972.

72) McDevitt, H. O., and M. Landy, Genetic Control of Immune Responsiveness 1-131. Academic Press. NY. 1972.

73) Pevzner, I., M.L. Kaeberle, and A. W. NordsKoG, Poultry Sci 52: 2073. 1973.

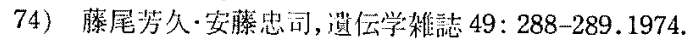

75) 敒藤怒二, 来発表

76) Hasen, M. P., J. N. Van Zandt, and G. R. J. Law, Poultry Sci 46: 1268. 1967.

77) Brewer, R. N., C. M. Moore, and L. W. Johnson, Poultry Sci 48: 1790. 1969.

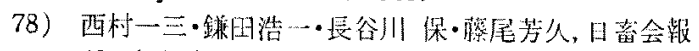
42：(则号): 105. 1971.

79) Johnson, L. W., Poultry Sci 52: 2045. 1973. 


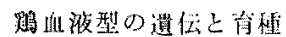

80) Crittenden, L. B., W. E. Briles, and H. A. Stone, Science 169: 1324-1325. 1970.

81) Crittenden, L.B., W. Okazaki, and R.H. Reamer, Nat Cancer Inst Monogr 17: 161-177. 1964.

82) Payne, L. N., and P. M. Blggs, Virology 29: 190198. 1966.

83) Rurin, H., Virology 26: 270-276. 1965.

84) Payne, L. N., and P. M. Brggs, J Gen Virol 7:
177-185. 1970.

85) Payne, L. N., and P.K. PhNi, J Gen Virol 13: 253-259. 1971.

86) Payne, L. N., P. K. Pani, and R. A. Weiss, J Gen Virol 13: 455-462. 1971.

87) Crittenden, T..B., E.J. Wendel, and I.V. Motta, Virology 52: 373-384. 1973. 